\section{A Dicentric Y Chromosome without Evidence of Sex Chromosomal Mosaicism, 46,XYqdic, in a Patient with Features of Turner's Syndrome}

Several examples of abnormal sexual or gonadal differentiation and structural anomalies of the $Y$ chromosome have been reported. Eight examples of 45,X/46,XYqdic have been reported (Table I). We present here another case of a dicentric $Y$ chromosome, in whom no evidence of mosaicism could be found.
She was $138 \mathrm{~cm}$ tall, weighed $43.7 \mathrm{~kg}$, and appeared unusually muscular and stocky. She had epicanthal of folds, a flattened nasal bridge, a high arched palate, a os short neck with slight pterygyum colli, and a low nuchal $\overrightarrow{0}$ hair line. The chest was wide with widely-spaced inverted nipples and small areolae. The external geni- $\vec{\omega}$ talia were unambiguously female but showed slight clitoral enlargement and hypoplastic labia. Pubic and axillary hair was scant and there was no breast develop- 0 ment. She had bilateral cubitus valgus and widelyspaced 1st and 2nd toes. There was no clinical evidence 8 of congenital cardiopathy, and the electrocardiogram was normal. She had an IQ of 70 (Therman-Merrill).

Radiological examination showed normal chest, long bones, and pelvis, with a bone age between 13 and 14 years. An excretory urogram was normal. Laparotomy revealed a small uterus, bilateral streak gonads in the

TABLE I

REPORTED CASES OF DICENTRIC Y CHROMOSOME (LONG ARM)

\begin{tabular}{|c|c|c|c|c|c|c|}
\hline $\begin{array}{l}\text { Presumptive } \\
\text { Karyotype }\end{array}$ & $\begin{array}{l}\text { Phenotypic } \\
\text { Sex }\end{array}$ & $\begin{array}{c}\text { Gonadal } \\
\text { Differentiation }\end{array}$ & Age & Stature & Remarks & Source \\
\hline 45,X/46,XYdic & Ambiguous & Testes in abdomen & $4 \mathrm{mth}$ & ? & & Yunis (1955) \\
\hline $45, \mathrm{X} / 46, \mathrm{XY}$ dic & Normal male & Testes & $24 \mathrm{yr}$ & $?$ & Father 46,XY & McIlree et al (1966) \\
\hline $45, X / 46, X Y d i c$ & Female & Bilateral streaks & $?$ & Short & $\begin{array}{c}\text { Features of Turner's } \\
\text { syndrome }\end{array}$ & $\begin{array}{l}\text { Quoted by McIlree } \\
\text { et al (1966) }\end{array}$ \\
\hline $45, \mathrm{X} / 46, \mathrm{XYdic}$ & Female & $?$ & $?$ & Short & $\begin{array}{c}\text { Features of Turner's } \\
\text { syndrome }\end{array}$ & $\begin{array}{l}\text { Quoted by McIlree } \\
\text { et al (1966) }\end{array}$ \\
\hline $45, \mathrm{X} / 46, \mathrm{XY}$ dic & Ambiguous & Inguinal testes & $3 \mathrm{yr}$ & $?$ & Father 46,XY & $\begin{array}{l}\text { Quoted by McIlree } \\
\text { et al (1966) }\end{array}$ \\
\hline $45, X / 46, X Y d i c$ & Female & $\begin{array}{l}\text { Left streak } \\
\text { Right inguinal testis }\end{array}$ & $13 \mathrm{yr}$ & $142 \mathrm{~cm}$ & $\begin{array}{l}\text { Turner's phenotype. Small } \\
\text { penis with severe } \\
\text { hypospadias; father } \\
46, \mathrm{XY}\end{array}$ & $\begin{array}{l}\text { Ferrier, Ferrier, } \\
\text { and Bill (1968) }\end{array}$ \\
\hline $45, X 46, X Y d i c$ & Female & $\begin{array}{l}\text { Bilateral streaks (one } \\
\text { single testicular tubule } \\
\text { observed in right } \\
\text { streak) }\end{array}$ & $14 \frac{1}{2} \mathrm{yr}$ & $138 \mathrm{~cm}$ & $\begin{array}{l}\text { Features of Turner's } \\
\text { syndrome }\end{array}$ & $\begin{array}{l}\text { Angell, Gianelli, } \\
\text { and Polani } \\
\text { (1970) }\end{array}$ \\
\hline $45, X / 46, X Y$ dic & Female & Bilateral streaks & $36 \mathrm{yr}$ & $147 \mathrm{~cm}$ & $\begin{array}{l}\text { Features of Turner's } \\
\text { syndrome }\end{array}$ & Angell et al (1970) \\
\hline $46, \mathrm{XYdic}$ & Female & Bilateral streaks & $16 \mathrm{yr}$ & $138 \mathrm{~cm}$ & $\begin{array}{l}\text { Features of Turner's } \\
\text { syndrome. Gonado- } \\
\text { blastoma; father 46,XY }\end{array}$ & Present case \\
\hline
\end{tabular}

\section{Case Report}

A 16-year-old girl was admitted to the Pediatric Hospital complaining of primary amenhorroea and lack of breast development. She was the product of a full term normal pregnancy and delivery. At her birth the mother and father were aged 22 and 28 respectively. She had no sibs. Her general health had been good.

Received 3 May 1971. position ordinarily occupied by ovaries, and bilateral Fallopian tubes. The streak gonads were removed.

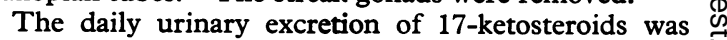
within normal limits before and after laparotomy. Twenty-four-hour urinary gonadotropin excretion inincreased from 58 rat units before the removal of the streak gonads to 138 rat units 6 months after the start of oestrogen and progesterone therapy. ${ }^{131}$ I uptake was $19 \%$ at 24 hours (normal range). 


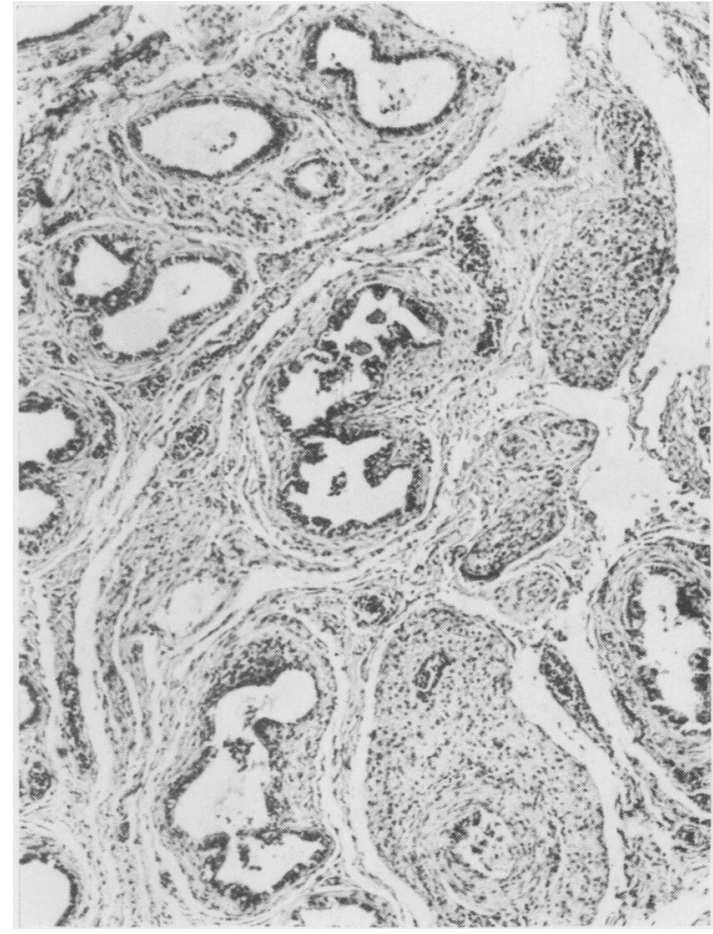

FIG. 1. Dilated and irregular tubules lined by columnar epithelium and surrounded by smooth muscle (epididymis). There are 2 nests of hilus cells.

\section{Histological Findings}

Microscopy of 4 separate pieces of gonadal tissue revealed in two of the slides a streak of dense fibrous tissue with ovarian stromal appearance and epididymis (Fig. 1). There were abundant hilus cells not only in the hilus, but also in the epididymis. Some of the hilus cells appear to contain lipochrome pigment. The other two slides showed what appear to be a hydatid of Morgagni. In the ovarian stroma were multiple hyalinized nodules, at least one of which contains the elements required for the diagnosis of gonadoblastoma (Fig. 2) (Scully, 1970). One nodule on each slide con-

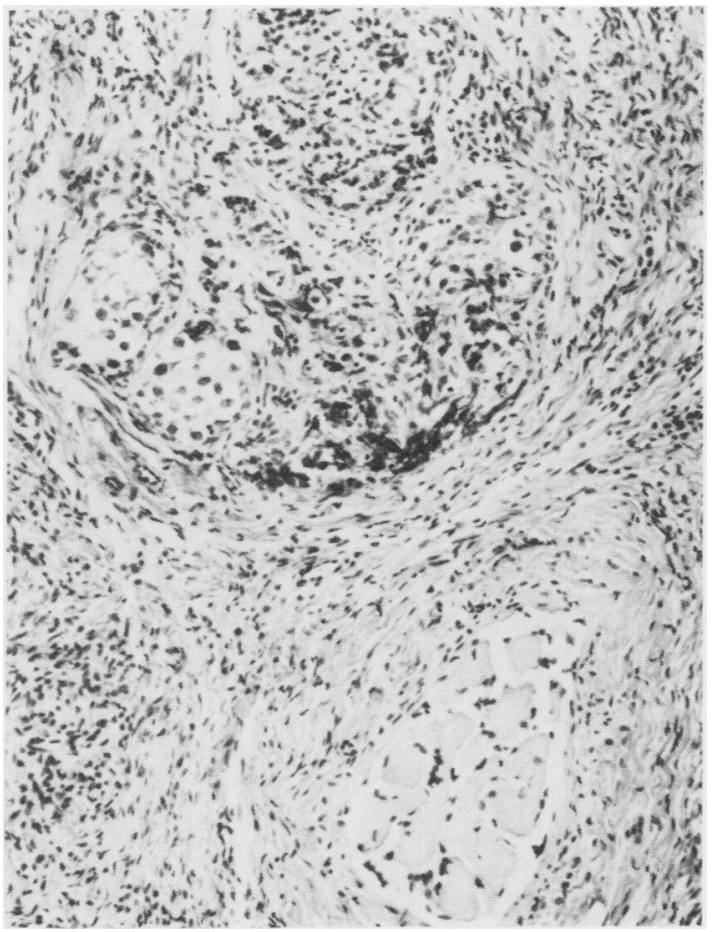

Fig. 2. Ovarian stroma with hyalinized nodules and the tiny gonadoblastoma.

tained both germ cells and immature sex cord elements; a few lymphocytes had infiltrated into these nodules. The architecture of the other hyaline nodules suggests that they may be foci of burned-out gonadoblastomas; one of them contains residual sex cord elements, but no germ cells.

\section{Dermatoglyphs}

Finger and palm prints of the patient showed an atd angle of $37^{\circ}$ for the left hand and $40^{\circ}$ for the right one. There were loops on $I_{1}, I_{3}$, and $I_{4}$ on the left hand and on $I_{3}$ on the right. The finger ridge pattern was $\mathrm{W}, \mathrm{W}$,

TABLE II

RESULTS OF CHROMOSOME ANALYSIS

\begin{tabular}{l|c|c|c|c|c|c}
\hline & \multicolumn{5}{|c}{ Chromosome Counts } \\
\cline { 2 - 7 } & $<45$ without Ydic & $<45$ with Ydic & 45 without Ydic & 45 with Ydic & 46,XYdic & Total \\
\hline Peripheral lymphocytes & 4 & 42 & 0 & 12 & 107 \\
\hline Bone marrow & 2 & 10 & 0 & 4 & 45 \\
\hline Skin fibroblasts & 3 & 11 & 0 & 9 & 27 & 50 \\
\hline
\end{tabular}




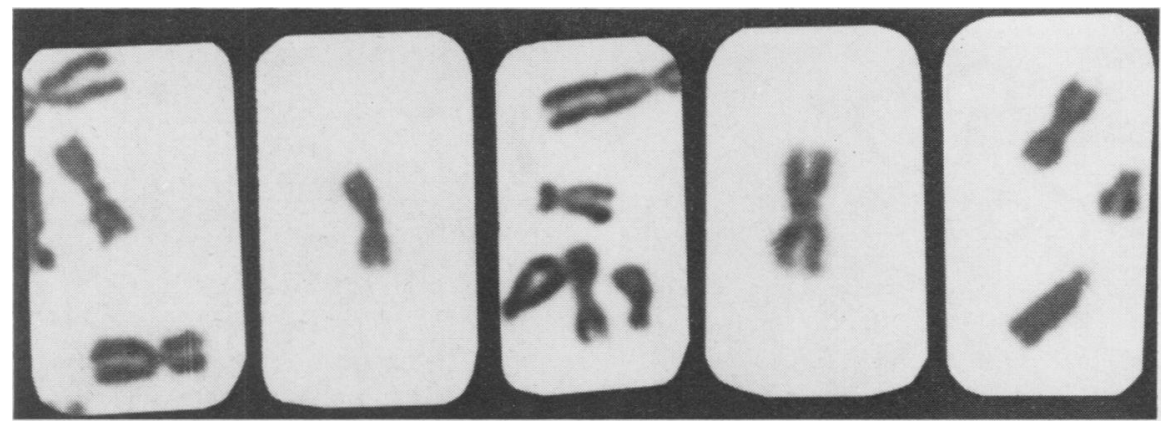

FIG. 3. Dicentric $\mathrm{Y}$ chromosomes from five different metaphases.

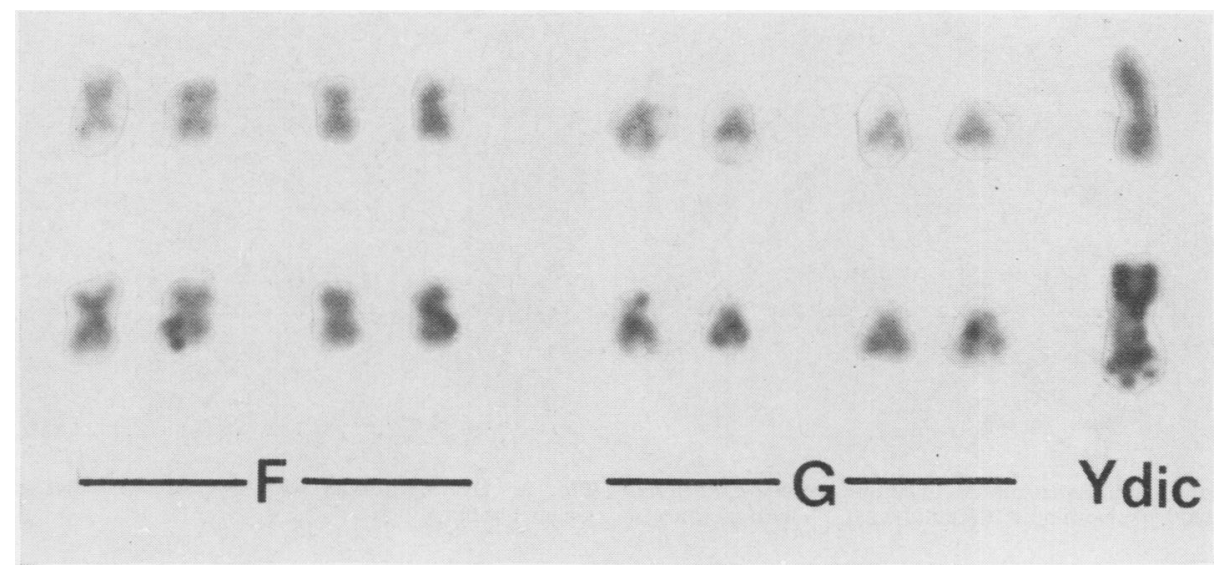

FIG. 4. Partial autoradiograph karyotype of the F and G groups including the dicentric $\mathrm{Y}$ chromosome showing similar late labelling on both long arms of the dicentric $\mathrm{Y}$ chromosome.

UL, $\mathbb{W}, \mathrm{UL}$ on the left hand and $\mathrm{W}, \mathbb{W}, \mathbb{W}, \mathbb{W}, \mathrm{UL}$ on the right. The total finger ridge count was 266 (mean for Mexican males $149.8 \pm 49.6$ and mean for Mexican females $139 \cdot 2 \pm 51 \cdot 7$; Zavala, González, and Lisker, 1969).

\section{Cytogenetics}

Chromosome analysis from cultures of peripheral blood lymphocytes, bone marrow cells, and skin fibroblasts, demonstrated a modal number of 46 without evidence of mosaicism (Table II). Cell culture from gonadal tissue failed to grow. An abnormal dicentric chromosome, with two symmetrical arms attached to a short intermediary segment lying between two clear constrictions and approximately twice the length of a G group chromosomes (Fig. 3), was observed in all the cells. The distal ends of the dicentric chromosome showed negative heteropyknosis and the chromatids more closely approximated to one another than those of the other small chromosomes. The patient was chromatin negative.

Autoradiographs (Schmid, 1963) showed that in the

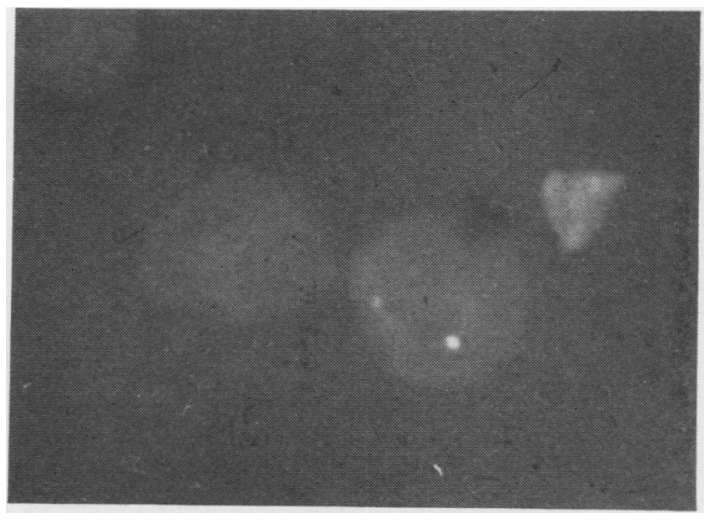

FIG. 5. Brightly fluorescent body in an interphase nucleus.

latter part of the $S$ period, the dicentric chromosome was heavily labelled throughout its length (Fig. 4) in 74 metaphase plates suitable for analysis. The labelling pattern was symmetrical over the long arms of the dicen- 
tric chromosome in 67 cells, and asymmetrical in 7 cells. The intermediate region was not labelled.

Buccal smears and slides from lymphocyte cultures were strained with quinacrine dihydrochloride ('Atebrin') (Caspersson et al, 1968; Pearson, Bobrow, and Vosa, 1970). A single large brightly fluorescent body was observed in a proportion of interphase nuclei in buccal smears (Fig. 5). It was frequently localized at the periphery of the nucleus, and in some of the cells the fluorescent body had a clear double structure. In cultured lymphocytes, the distal half of both arms of the dicentric chromosome was the brightly fluorescent and each arm corresponded to the pattern usually seen in the human Y chromosome.

Both parents had normal karyotypes. The length of the long arm of the father's $Y$ chromosome is similar to the length of the long arms of the dicentric Y chromosome of the proposita.

\section{Discussion}

The abnormal chromosome is considered to be a dicentric Y chromosome with characteristic autoradiographic, morphological, fluorescent patterns. It is approximately twice the length of the father's $Y$ chromosome, with two clearly visible centromeres. The lack of evidence of mosaicism suggests that the most likely karyotype is $46, \mathrm{XY}$ qdic. The failure to show a 45,X cell line does not mean that a low frequency of $45, \mathrm{X}$ cells may not be present. Nevertheless, our findings indicate that the dicentric chromosome is quite stable. This is noteworthy because dicentric chromosomes, like ring chromosomes, are believed generally to be unstable structures, and in the 8 instances of dicentric $\mathrm{Y}$ chromosome so far observed, mosaicism has been found, suggesting a post-zygotic origin or at least instability (loss at division). However, in humans, relatively stable dicentric chromosome have been observed (de la Chapelle et al, 1966). In our case the stability of the dicentric $\mathrm{Y}$ chromosome may be explained because the two centromeres are both situated sufficiently close together to act as one, or perhaps because one of the centromeres is dominant (Sears and Camara, 1952). In the subjects with a dicentric $Y$ chromosome so far reported (Table I), in which the $\mathrm{Y}$ chromosome of the male relatives was normal, the abnormal $Y$ was presumed to have arisen as result of a break in the short arms after chromatid duplication followed by sister chromatid reunion and loss of the material distal to the break. This could have occurred during spermatogenesis with mosaicism arising as a post-zygotic event, or it could itself have occurred subsequent to the formation of the zygote (Jacobs, 1969).

In the individuals with dicentric $\mathrm{Y}$ chromosome so far reported, the phenotypic sex and the gonadal differentiation has been variable (Table I). This variation may depend on whether or not the genes controlling the development of the testes are included in the portion of the short arms which is eliminated during the rearrangement. In the $45, \mathrm{X} / 46, \mathrm{XY}$ dic case the failure of testicular differentiation may be attributed to the presence of the $45, \mathrm{X}$ cell line. The suggestion that the genes responsible for testicular differentiation are located on the short arm of the human $\mathrm{Y}$ chromosome comes from several sources (Ferguson-Smith, 1965; Jacobs and Ross, 1966; McIlree et al, 1966; Court Brown, 1967); further, Jacobs (1969) presented some evidence that supports the idea 'that the testicular determining genes, if present on the short arm, must be situated near the centromere'.

There is, however, slightly contradictory evidence suggesting that the male-determining genes are situated on the long arms of the Y (Federman, Davidoff, and Oullette, 1967; Sarto, Opitz, and Inhorn, 1969) and it is worthwhile mentioning that recently Ferguson-Smith et al (1969) reported a woman with a chromosome mosaicism 45,X/ $46, \mathrm{XYqi}$ and the presence at necropsy of rudimentary epididymis and other mesonephric structures which suggest to the authors 'that factors on the long arm as well as on the short arm of the human $\mathrm{Y}$ chromosome play a part in male determination'.

This possibility must be considered here, because the histological study showed epididymal structures and it may suggest that during embryogenesis there was some, although insufficient, testicular differentiation to induce normal development of Wolffian ducts, and it may imply that some testicular-determining factors are on the long arm of the $\mathrm{Y}$ chromosome. Concerning the gonadoblastoma, this is relatively common in individuals with gonadal dysgenesis and a $\mathrm{Y}$ chromosome in at least one cell line (Teter and Boczkowski, 1967).

\section{Summary}

A patient with features of Turner's syndrome, streak gonads, and a sex chromosome complement $\mathrm{XYdic}$ without evidence of mosaicism is reported. The histological studies showed ovarian-like stroma, epidedymis, and a small gonadoblastoma. The phenotypic sex and gonadal differentiation supports the idea that testicular determining genes are on the short arm of the $\mathrm{Y}$ chromosome, near the centromere but not immediate to it. The possibility that some male determinants factors could be on the long arms cannot be definitively ruled out. 
We are indebted to Dr R. E. Scully, Harvard Medical School, and Dr H. Márquez-Monter, Department of Investigation, I.M.S.S., México, for the interpretation of the histological slides. We are grateful to $\mathrm{Dr}$ J. L. German, New York Blood Center, for reading the manuscript and for making very helpful suggestions.

Salvador Armendares,* Leonor Buentello, Fabio Salamanca, and Jose-Maria Cantu-Garza

\section{The Genetics Section of the Departments of Investigation and Medical Genetics, Hospital de Pediatria, Instituto Mexicano del Seguro Social, México, DF, Mexico}

\section{REFERENCES}

Angell, R., Giannelli, F., and Polani, P. E. (1970). Three dicentric Y chromosomes. Annals of Human Genetics, 34, 39-50.

Caspersson, T., Farber, S., Folley, G. E., Kudynowski, J., Modest, E. J., Simonsson, E., Wagh, U., and Zech, L. (1968). Chemical differentiation along metaphase chromosomes. Experimental Cell Research, 49, 219-222.

Court Brown, W. M. (1967). Human Population Cytogenetics (vol. 5 of 'Frontiers of Biology'), ed. by A. Neuberger and E. L. Tatum. North-Holland Publishing Co., Amsterdam.

De la Chapelle, A., Wennström, J., Hortling, H., and Ockey, C. H. (1966). Isochromosome-X in man. Part I. Hereditas, Genetiskt Arkiv, 54, 260.

Federman, D. D., Davidoff, F. M., and Ouellette, E. (1967). Presumptive $\mathbf{Y} / \mathrm{D}$ translocation in mixed gonadal dysgenesis. Fournal of Medical Genetics, 4, 36-40.

Ferguson-Smith, M. A. (1965). Karyotype-phenotype correlations in gonadal dysgenesis and their bearing on the pathogenesis of malformations. Fournal of Medical Genetics, 2, 142-155.

Ferguson-Smith, M. A., Boyd, E., Ferguson-Smith, M. E., Pritchard, J. G., Yusuf, A. F. M., and Gray, B. (1969). Isochromosome for long arm of $\mathrm{Y}$ chromosome in patient with Turner's syndrome and sex chromosome mosaicism (45,X/46,XYqi). fournal of Medical Genetics, 6, 422-425.

Ferrier, P. E., Ferrier, S. A., and Bill, A. H. (1968). A male pseudohermaphrodite with a dicentric Y chromosome. Humangenetik, 6, 131-141.

Jacobs, P. A. (1969). Structural abnormalities of the sex chromosomes. British Medical Bulletin, 25, 94-98.

Jacobs, P. A. and Ross, A. (1966). Structural abnormalities of the $Y$ chromosome in man. Nature, 210, 352-354.

McIlree, M. E., Price, W. H., Court Brown, W. M., Tulloch, W. S., Newsam, J. E., and Maclean, N. (1966). Chromosome studies on testicular cells from 50 subfertile men. Lancet, 2, 69-71.

Pearson, P. L., Bobrow, M., and Vosa, C. G. (1970). Technique for identifying $\mathrm{Y}$ chromosomes in human interphase nuclei. Nature, 226, 78-80.

Sarto, G. E., Opitz, J. M., and Inhorn, S. L. (1969). Considerations of sex chromosome abnormalities in man. In Comparative Mammalian Cytogenetics, pp. 390-413. Springer-Verlag, New York.

Schmid, W. (1963). DNA replication patterns of human chromosomes. Cytogenetics, 2, 175-193.

Scully, R. E. (1970). Gonadoblastoma. A review of 74 cases. Cancer, 25, 1340-1356.

Sears, E. R. and Camara, A. (1952). A transmissible dicentric chromosome. Genetics, 37, 125.

* Present address: Department of Medical Genetics, Hospital de Pediatría, Centro Médico Nacional, Av. Cuauhtémoc 330, México 7,
DF, México.
Teter, J. and Boczkowski, K. (1967). Occurrence of tumors in dysgenetic gonads. Cancer, 20, 1301-1310.

Yunis, J. J. (1965). Human Chromosome Methodology, p. 187. Academic Press, New York and London.

Zavala, C., González, G., and Lisker, R. (1969). Dermatoglyphic patterns in a sample of normal urban Mexicans. Human Heredity, 19, 534-539.

\section{Turner's Syndrome with Menstruation}

In 1938 Turner described a syndrome characterized by gonadal dysgenesis, primary amenorrhoea, short stature, and various somatic malformations. About 20 cases of Turner's syndrome with short menstrual periods have been published (Zarate et al, 1969; Kaufman et al, 1971) and it seemed useful to report a rare case of Turner's syndrome with regular menstruation and a 45,X karyotype.

\section{Case Report}

The family history was unremarkable. After finishing elementary school with satisfactory results the patient, Margot A., a maid born 5 December 1950, now lives with her mother whom she occasionally helps with the house work.

Case History. No complications were reported until 1954 when dysuria occurred. Radiology of both kidneys showed a slightly impaired function of the left kidney while the right kidney showed no function at all. $X$-rays of the retroperitoneal cavity showed the left kidney as a markedly enlarged shadow and the right kidney appeared very large and shapeless.

Blood urea and uric acid serum levels were within the normal limits, and the blood pressure was not elevated.

A right nephrectomy was performed on 10 January 1964 and a double kidney with mega-ureters removed; there were no postoperative complications.

Gynaecological History. Menarche commenced at 14 years. The cycle was 28 to 30 days with medium heavy bleeding which lasted 5 to 6 days.

Clinical Studies. When seen in 1970 this 20 -yearold girl was $143 \mathrm{~cm}$ in height and weighed $59.9 \mathrm{~kg}$; she was moderately obese. The following anomalies were noted; epicanthus, gothic palate, micrognathia, a suggestion of cutis laxa, funnel chest, hyperelasticity of the joints, bilateral cubitus valgus, and hypoplastic (pseudohypertrophic) skeletal muscles. The clinical examination of the internal organs failed to reveal any patho-

Received 30 April 1971 